\title{
The Role of Land Speculators around the Urban Edge of Shashemene City, Ethiopia
}

\author{
Bedane Shata Gemeda ${ }^{1^{\star}}$, Berhanu Girma Abebe ${ }^{2^{\star \star}}$, Giuseppe T. Cirella ${ }^{3^{* \star \star}}$
}

\author{
${ }^{1} \mathrm{PhD}$ candidate at Ethiopian Institute of Architecture, Building Construction and City Development, Addis Ababa University, ETHIOPIA \\ ${ }^{2}$ Assistant Professor at Ethiopian Institute of Architecture, Building Construction and City Development, Addis Ababa University, ETHIOPIA \\ ${ }^{3}$ Professor at Faculty of Economics, University of Gdansk, POLAND \\ *Corresponding Author: bedanes@yahoo.com \\ **Corresponding Author: mesi.bire@gmail.com \\ ${ }^{\star \star \star}$ Corresponding Author: gt.cirella@ug.edu.pl
}

Citation: Gemeda, B. S., Abebe, B. G., \& Cirella, G. T. (2020). The Role of Land Speculators around the Urban Edge of Shashemene City, Ethiopia. European Journal of Sustainable Development Research, 4(1), em0108. https://doi.org/10.29333/ejosdr/6296

\begin{abstract}
ARTICLE INFO
Received: 02 Aug. 2019

Revised: 16 Sep. 2019

Accepted: 30 Sep. 2019

ABSTRACT

The high demand for land provides land speculators the opportunity to hold land in anticipation of a price increase over time. Although the objective of the 1993 Land Use Statement was to test extra land speculation, the announcement has only been successful in fueling it. This study examines the role of land speculators around the outer edge of Shashemene's metropolitan area. Primary data for this study was collected through a questionnaire with 73 respondents who were sampled using snowball sampling techniques. The chief findings of this study reveal that land speculation is still practiced in the study area, and the respondents affirmed that land speculators engaged in land speculation mostly for economic benefits.
\end{abstract}

Keywords: taxation, snowballing techniques, land speculation, Ethiopia

\section{INTRODUCTION}

Land, although ordinary, is a useful resource that requires improvement. Land misuse does not lead to the wastage of a scarce resource; rather, it influences various improvement sectors (Andreasson, 2015). Proper land use requires registering land rights and conditions of use and facilitating a clean switch to different customers on a market precept or otherwise (Onokerhoraye, 2010). According to Onokerhoraye (2010), the problem of land being available anywhere in the world is one of the most pressing aspects for humans economically, politically, and socially. Land has long been the primary cause of controversies, disputes, or conflicts between individuals, groups, societies, and international locations. Furthermore, land ownership is a primary trading state for individuals, societies, and governments (Yirsaw, 2010). In this view, the need to develop occupancy to precede socialist international locations is by no means a challenge left unmet. Each boom is based on tenable land ownership. Those nations that witness extensive registration and safeguarding of land and deal with issues equally undergo a tremendous degree of economic progress. As a result, many former socialist international locations could have made radical adjustments for the coverage of use of land and land-associated sources, to boost monetary development (Colin, 2013). As studies show a number of metropolitan administrators may have used income from land and land-related tendencies to protect costs used for infrastructure and various urban development activities (Abrahamson, 1983).

Historically speaking, land is the construct for a sustainable society (Colin, 2013). Admission to land in Ethiopia has been broadly explained by the 1993 declaration No, 80/1993, Art, 5-7 Land Use. Land can be allocated by the government either through the statutory or customary allocation of the right of occupation to an individual or corporate body (FDRE, 1993). The declaration No, 80/1993, Art, 5-7 Land Use conferred all land rights in urban areas. The Governor of the Federal Ministry on whose behalf and with the express consent of which any grant of land rights would henceforth be made. It went further to state that all lands in Urban Centers shall be under the track and administration of the ruler (Adam, 2014c).

The statement also states that all land holdings in urban centers are now considered to be statutory holdings, so holders can only apply for occupancy certificates if they so desire. Individuals and organizations can apply through their agencies for the government's land allocation through this assertion. Despite the fact that section (1 to 4) stipulates the maximum allocation of $500 \mathrm{~m}^{2}$ of residential land to a single title holder in the urban area, there is no clear confirmation that this provision is enforced by the government (FDRE, 1993). Unchecked cases of multiple allocations to individuals became very common and caused land speculation to surface. Likewise speculations escort to dearth of development land which therefore results in a rising cost of land in the informal land market and also resulted in. continuous urban sprawl (Mayo and Sheppard, 2001). 


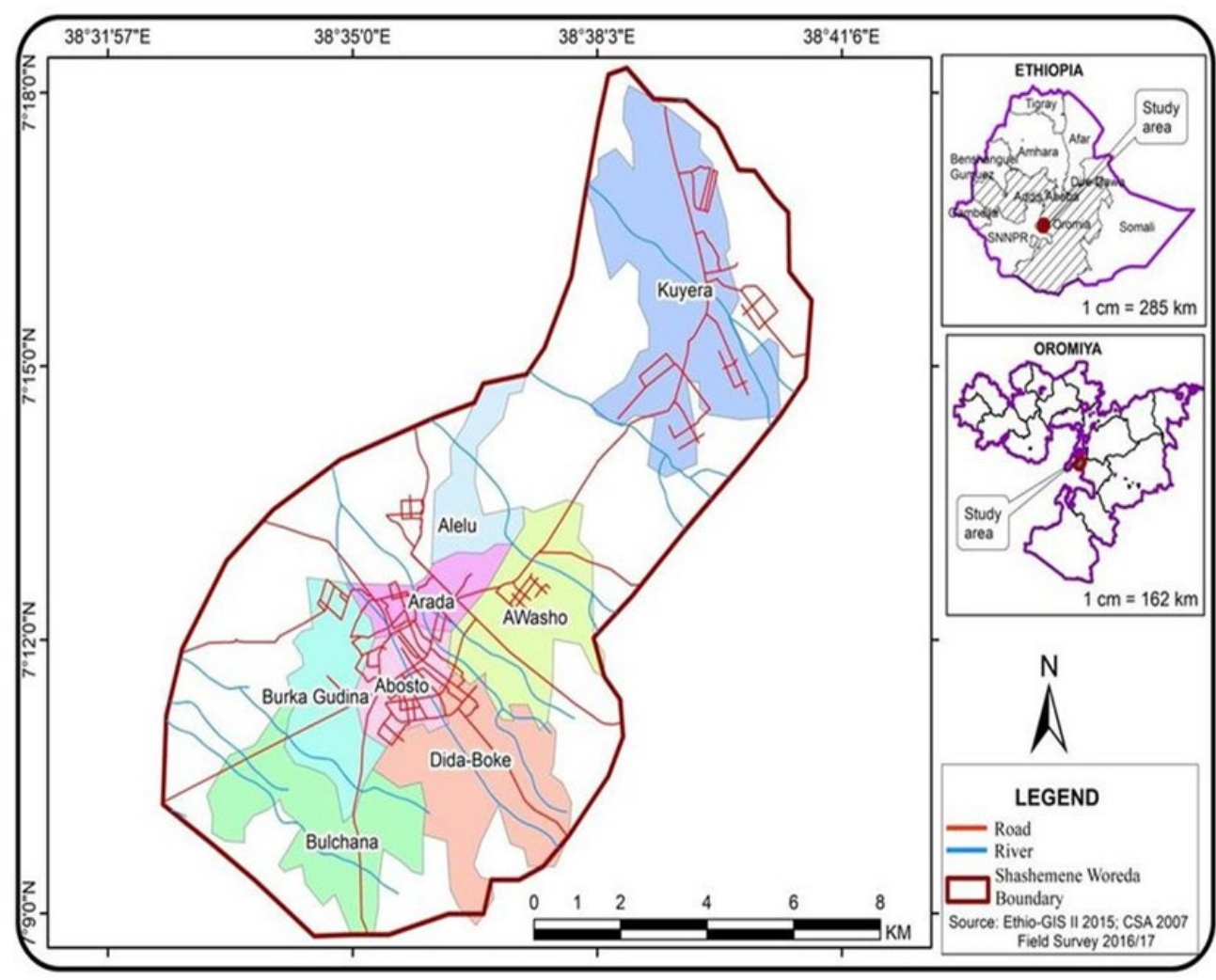

Figure 1. Location Map of Shashemene

The term speculation is used to mean something about the investor's time perspective. The time period is used in a few cases to denote fast-range investors instead of buying and maintaining individuals. It is also used to identify buyers who buy (or alternate or in any other case reap control of) a parcel of land but keep it vacant (or in cutting-edge, much less extensive use) within the expectation of a future opportunity for money-making improvement. In this sense, the question of the first timing of improvement is warmly certain of speculation (Capozza, 1976; Mayo and Sheppard, 2001; Titman, 1985).

Speedy urban growth has placed great pressure on land in Ethiopian cities, especially in the remaining many years. The number of settlers living in towns and cities in Ethiopia is forecast to reach 120 million over the next 13 years, reaching one hundred and fifty million by 2030 (World Bank, 1996). There are many results, especially for urban development and land control. The Federal Government of Ethiopia (FGE) has observed that the out - of-control nature of urban improvement is introduced through the great difficulty, skilled through people and enterprising our bodies in providing access to buildings (EPRDF, 2005a).

Despite the fact that one of the main objectives of the No, 8/1993, Art, 5-7 Land Use announcement is to curtail land speculation, the announcement has facilitated rather than discouraging hypothesis (Adam, 2014c). The assertion abolished private land ownership and transferred all land under management and subject to rich investors' disposal. This ended in largescale speculative buying of large land tracts, mainly in the absence of land taxes. Most of these purchases were made through rich non-farmers who held the land idle and were willing to capitalize on the appropriate marketplace situation (Abiyi, 1984).

This study seeks to examine the role of land speculators around the outer edge of the metropolitan area. In order to obtain the above precise intention, the subsequent particular goals are pursued: i) to identify the major land speculators and their socioeconomic situations ii) examining their attitudes and behaviors with regards to land speculation ii) exploring how their activities affect the city growth and development.

\section{MATERIALS AND METHODS}

\section{Study Area}

Shashemene is a city in the West Arsi Zone, Oromia Region, Ethiopia, and a separate district. It is about $250 \mathrm{~km}$ from Addis Ababa Capital. It has $7^{\circ} 12^{\prime}$ north latitude and $38^{\circ} 36^{\prime}$ east longitude. In addition, Shashemene is surrounded in all directions by lands covering a total area of approximately $12,994.61$ hectares. The distance is about $12 \mathrm{~km}$ from the extreme points from north to south and $8 \mathrm{~km}$ from the extreme points from east to west. Shashemene has been the largest and most influential commercial city in the Oromia region for many centuries. Most likely, the settlement is 100 years old and was first placed in Abaro Hill neighborhood (CSA, 2007).

As cautioned with Adam's (2014), after autonomy, many cities witnessed excellent urbanization and rapid population growth due to socio-economic transformation that includes improving commercial, residential and business land that makes use of. Turn appealed to other socio-economic sports that led to metropolitan expansion. 
Table 1. Population growth of Metropolitan Shashemene 2006-2017

\begin{tabular}{rrr}
\hline Year & Population & Source of projection \\
\hline 2006 & 49,000 & SWFED \\
\hline 2007 & 51,234 & SWFED \\
\hline 2008 & 53,123 & SWFED \\
\hline 2009 & 55,567 & SWFED \\
\hline 2010 & 57,634 & SWFED \\
\hline 2011 & 59,563 & SWFED \\
\hline 2012 & 61,541 & SWFED \\
\hline 2013 & 63,253 & SWFED \\
\hline 2014 & 65,459 & SWFED \\
\hline 2015 & 67,120 & SWFED \\
\hline 2016 & 69,450 & SWFED \\
\hline 2017 & 72,090 & SWFED
\end{tabular}

Source: Shashemene Woreda Finance and Economic Development Office, 2017

These socio-economic renovations attracted migrants from other parts of the state as well as other parts of the country, culminating in the rapid peripheral population growth from 49,000 in 1999 to around 69,450 in 2009. Metropolitan area currently has a population of about 72,000 based on an annual growth rate of 3.3 percent as shown by the provisional population and housing census figures for 2006 (CSA, 2007). This population growth resulted in the outward expansion of the city. A large number of immigrants invading the city resulted in urban sprawl. Migrants found that house rents were not affordable in the established areas. Even those already within the city found expansion difficult due to natural increase and an extended family system coupled with speculative land dealing. This resulted in the emergence of unauthorized settlement in the suburbs of Shashemene, mostly along the major routes into the city.

\section{Methodology}

A combination of purposeful sampling process and snowball sampling techniques were used in conducting this research. Purpose sampling is a type of non-probability sampling where the researcher picks those cases or populations that are considered to be typical or likely to have the desired set of information or attribute for inclusion in the sample (Obikeze, 1986). The purposeful sampling technique undertaken here involves detecting large landowners known to City Land Agency (SCLA) officials. Efforts have been made to obtain landowners' names and addresses from land dealers, district heads. In this way, the names collected from the field were compared to shun name repetition. A total of 36 names from Shashemene City Land Agency (SCLA) were obtained. These names served as the initial sample frame and based on the list of names, the snowballing technique was used. A total of 73 respondents were selected from this using the two methods specified above. The Snowball method involves asking the primary interviewee to call various recognized landowners who may be included in the pattern. The same applied to successive owners of land. The essence of this was to ensure that no other major land owners were left out of the list. Snowballing technique was also employed here because of the fact that it is one of the best ways of reaching those developers who usually prefer to operate without much publicity (Abrahamson, 1983).

Likewise, questionnaires were designed to acquire general and specific information about the respondents' activities and behaviors as well as the function of their production. The questionnaire was analytical as well as evaluative. The design was a combination of collecting facts directly ahead and measuring outlooks. In addition, the researcher relied heavily on the abovementioned statistics series techniques, such as published and unpublished materials, newspapers (including e-Journals), articles, textbooks, and the Internet.

\section{Tools of analysis and techniques of data presentation}

In analyzing the responses to the questionnaire statistical graphs showing frequency and percentages were used. Graphs were followed with the descriptive analysis of the findings.

\section{RESULTS AND DISCUSSION}

Investigation in to the socio-economic characteristics of the respondents shows that 31 and $43 \%$ of the sampled respondents are between the ages of 40 years and above as well as 30-40 years respectively. The sex distribution of the respondents shows a figure of $89 \%$ males and $11 \%$ females and this may not be unrelated to the cultural practices of the people in the study area where male gender dominates almost all aspects of life. The educational background of the respondents shows that majority of the respondents (35\%) attended secondary schools, 33\% attended primary schools and 32\% attended tertiary schools. Investigating data regarding the respondents' major profession reveals that $20 \%$ of respondents are businessmen, $10 \%$ are civil servants, and $54 \%$ are land and property developers (Table 2). The conclusion of this finding is that mass of respondents have one form of a main occupation with land dealing / speculation as a secondary occupation or preoccupation. The proceeds of the main occupation are used to buy land for both development and speculative purposes. The point here is that those that slot in landrelated matters particularly development, sales and purchases have varied ways and manners in which business/economic goal or aim is planned and executed. 
Table 2. Socio-economic characteristics of respondents

\begin{tabular}{|c|c|c|}
\hline Socio-economic characteristics & Frequency & Percentage \\
\hline \multicolumn{3}{|l|}{ Age } \\
\hline $20-30$ years & 19 & 26 \\
\hline $30-40$ years & 23 & 31 \\
\hline Above 40 years & 31 & 43 \\
\hline \multicolumn{3}{|l|}{ Sex } \\
\hline Male & 65 & 89 \\
\hline Female & 8 & 11 \\
\hline \multicolumn{3}{|l|}{ Educational background } \\
\hline Primary & 24 & 33 \\
\hline Secondary & 26 & 35 \\
\hline Tertiary & 23 & 32 \\
\hline \multicolumn{3}{|l|}{ Main occupation } \\
\hline Business & 20 & 27 \\
\hline Civil servants & 10 & 13 \\
\hline Land/property developers & 40 & 54 \\
\hline Others & 3 & 6 \\
\hline
\end{tabular}

Source: Researcher fieldwork 2017

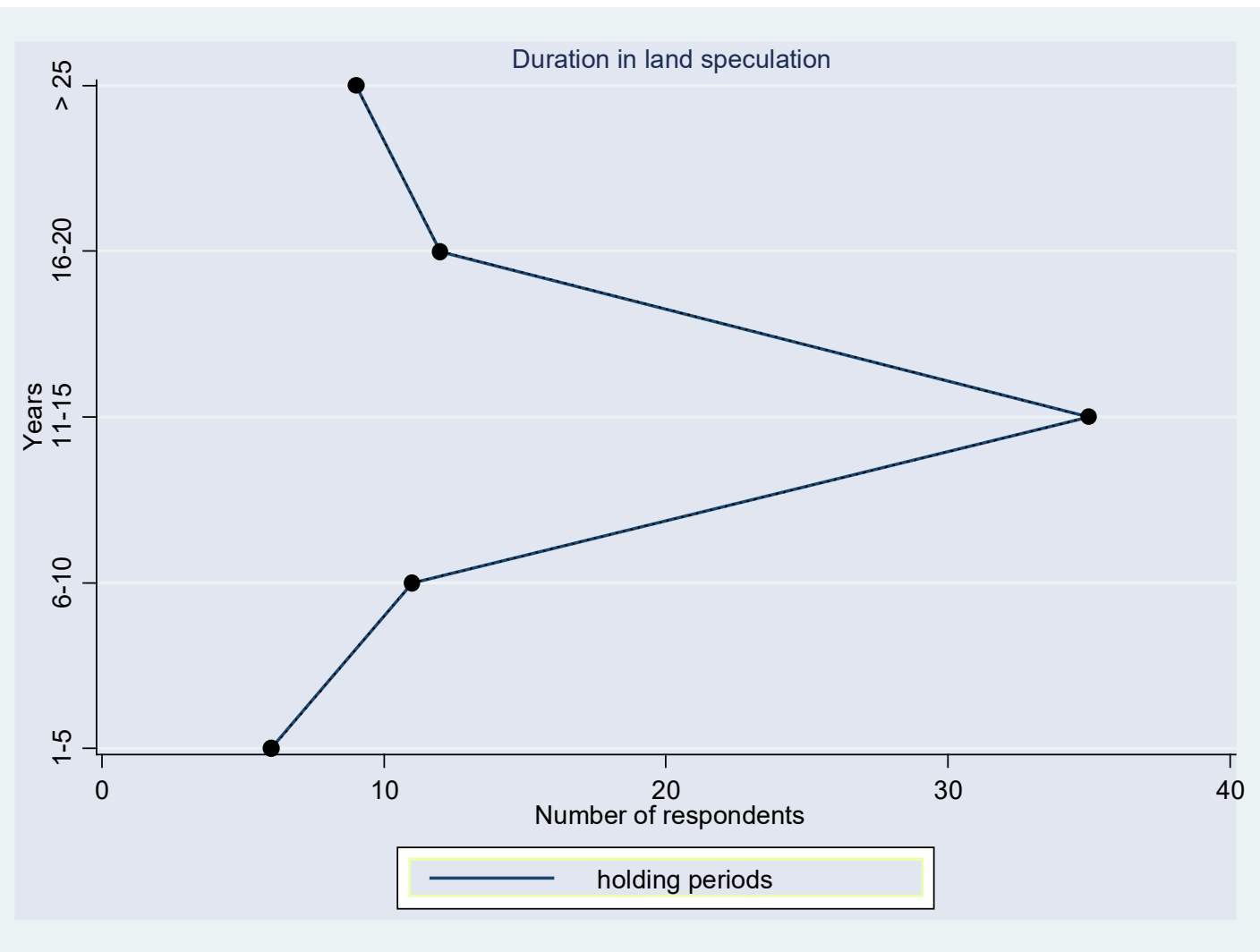

Figure 2. Duration in land speculation

Source: Researcher fieldwork 2017

In order to have an imminent view of land speculation, it is necessary to look at the period in which respondents were involved in speculation. This will provide crucial information about their length of practices and changes that they may have undergone in the course of speculative activity over the years. Approximately $35 \%$ of respondents have been involved in speculation for 15 years, $10 \%$ have been involved for 10 years and $9 \%$ have been involved for more than 20 years. From Figure 2 it can be concluded that the rate at which metropolitan Shashemene is rapidly growing is associated with the duration of land speculators in development industry. Coverage of residential land use rose from $12,800 \mathrm{~m}^{2}$ in 1999/2006 to $31,114.5 \mathrm{~m}^{2}$ in 2009/2016, while commercial land use increased from $12,510 \mathrm{~m}^{2}$ in $1999 / 2006$ to $26,098 \mathrm{~m}^{2}$ in 2009/2016 and industrial land use increased from $12,012.83 \mathrm{~m}^{2}$ in $1999 / 2006$ to $22,227.19 \mathrm{~m}^{2}$ in 2009/2016. The percentage coverage of different land uses from 1999/2006 to 2009/2016 had changed dramatically due to population growth and redistribution of economic activities in metropolitan Shashemene. Experience has shown expansion or growth of cities and towns is a product of population growth (Adam, 2014). The growth in population attached with economic growth will result in mass development of property to accommodate the increasing number of migrants into the city and for this to be achieved land is required to ensure housing the populace. This led to the explosion of land speculation. 


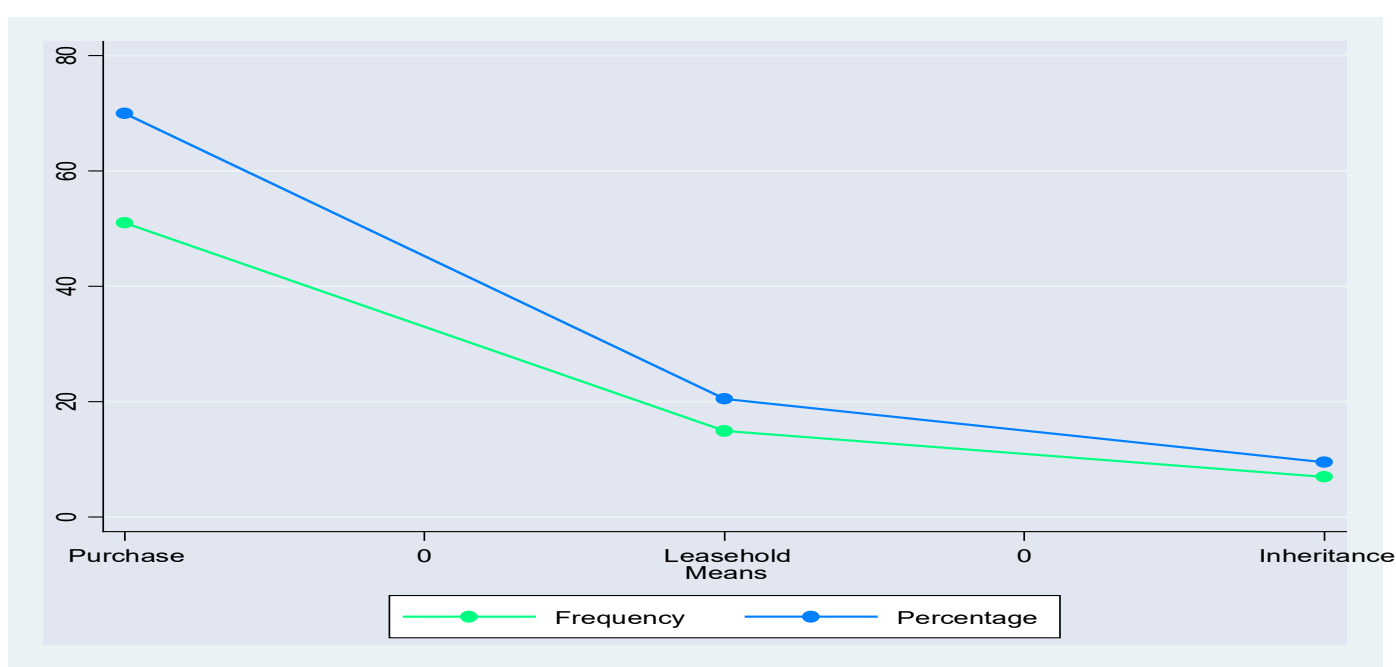

Figure 3. Means of land acquisition

Source: Researcher fieldwork 2017

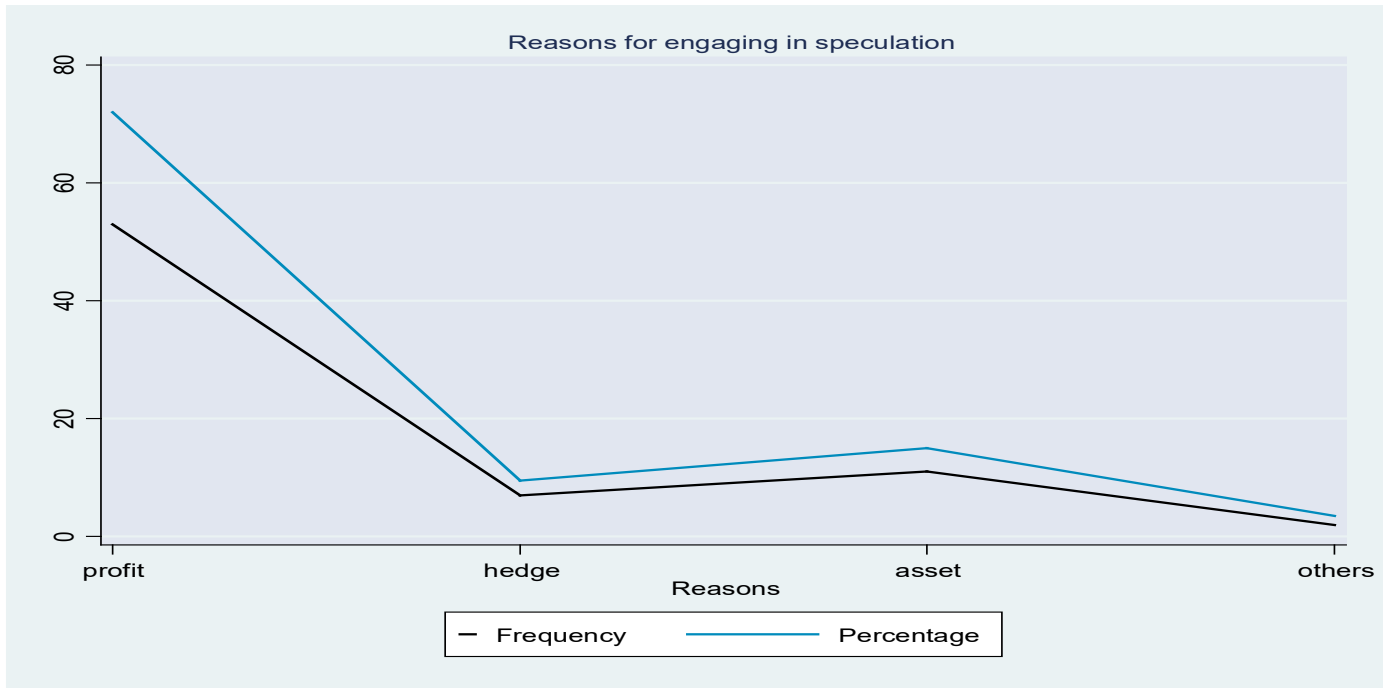

Figure 4. Reason(s) for engaging in land speculation

Source: Researcher fieldwork 2017

Figure 3 shows that $70 \%$ of the respondents get land through purchase, 20.5\% through leasehold, 9.5\% through inheritance on the source of the above purchase and leasehold accounts for the main means of land gaining.

Leasehold refers to a situation where a freehold landlord (usually the state) relinquishes its right of occupancy to another person for a given period of time after which the land will relapse to its originals owner. In Ethiopia, leasehold is usually for either 15 or 99 years.

Purchase refers to disaffection or land transfer in return for cash. High population growth, culminating in land shortages, competition for farmland between developers / and speculators on the one hand, and public acquisition on the other, necessitated the increasing purchase rate. In real sense, land hoarding has been increasing over the years mostly by private developers and it occurs as a result of socio-economic and demographic growth. On this basis, it is clear that the acquisition of land by means other than informal purchases is difficult. Furthermore, the rate of land purchase relays on the demand and cost of the land as well as prevailing economic situation also determines the rate of land purchase. A vivacious economic situation results in mass property construction and consequent rise in the selling price of land. On the other hand, in the period of the economic downturn there tends to be a slump in the development of the property and this, in turn, affects the price of a parcel of land.

Data analysis in Figure 4 shows that there are many reasons why people are involved in land speculation. Approximately 94 percent of the sampled respondents were engaged for financial reasons, which range from making profits from investment (72\%) to asset / security land (12\%) and land as a critical hedge against inflation (10\%). Similarly, $6 \%$ of respondents claimed pride and occupation of the owner as their motive for land speculation involvement. The occupation of the owner is mainly for the use of his children or relatives by the owner (developer).

It is considerable for nation here that the profitability criterion affects the hobbies of each element of land speculator, including its desire process, site selection, as well as land or landed asset selling costs. Consequently, in real sense, every aspect of the land hypothesis is guided and formed by monetary considerations. 


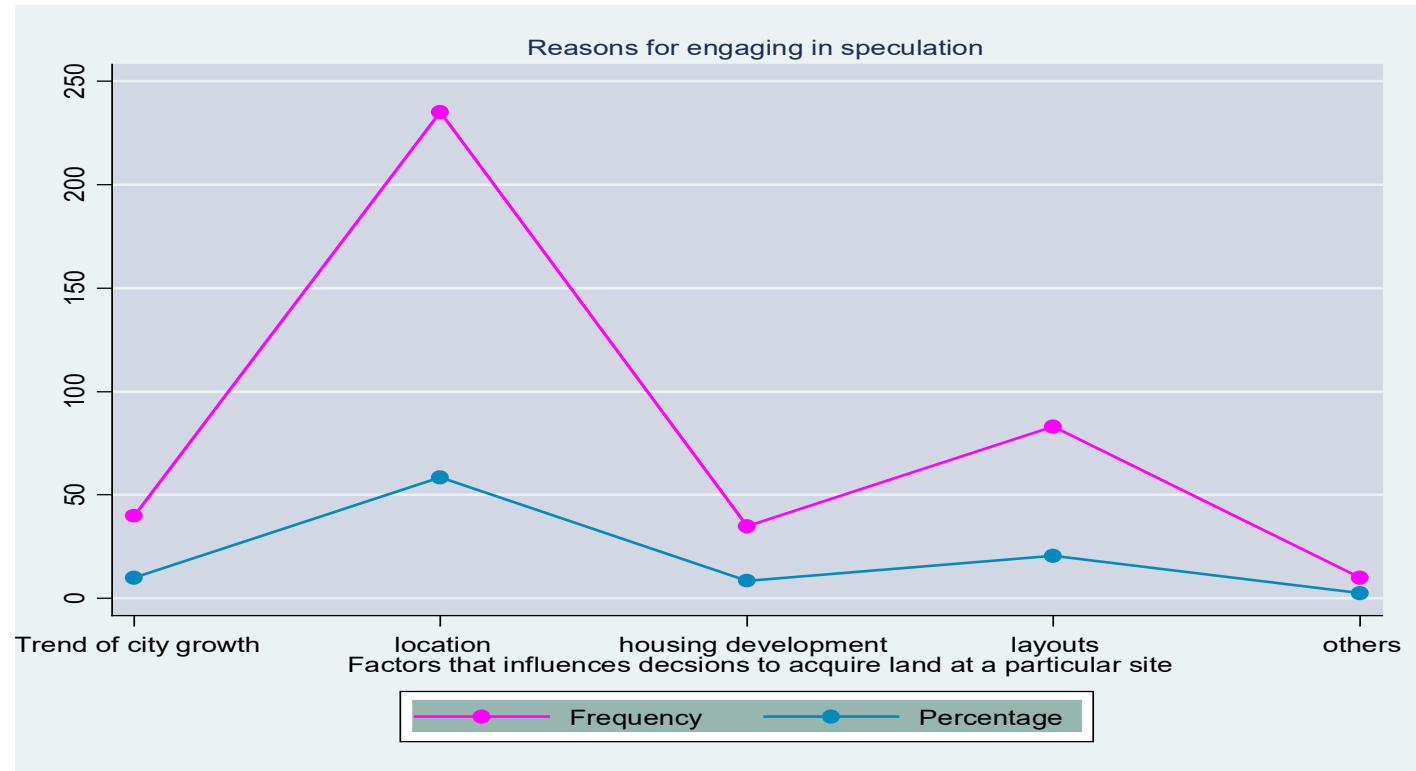

Figure 5. Factors that influence decisions to acquire land at a particular site Source: Researcher fieldwork 2017

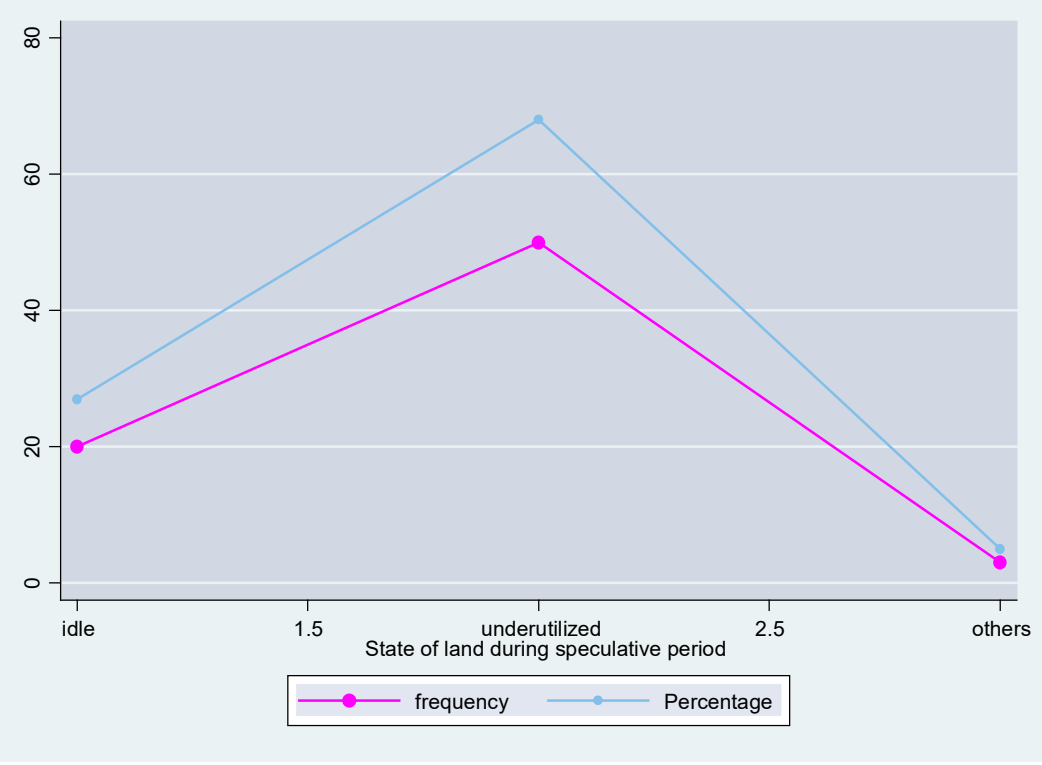

Figure 6. State of land during the speculative period Source: Researcher fieldwork 2017

Sampled respondents cited several factors affecting their decision to acquire land at a specific site or location. Approximately 9.9 percent (each) cited city growth trend, 58.5 percent of infrastructure / facilities or utilities available and new residential layouts created. Similarly, $8.6 \%$ stated that the initiation of housing development was the factor influencing their decision to acquire land at a specific location (Figure 5). Other respondents cited other reasons such as resemblance and affinity to an area as the major factor influencing their decision to acquire land in a given area. Additional analysis reveals that some of the respondents are reknown property developers and have friends both within the City Land Agency and the City Building Agency who provide insight into the government's plan to create residential layouts around the metropolis' fringe. In most cases, planners influence the city's growth trend by focusing on areas where infrastructure has been provided or is about to be provided.

Data analysis in Figure 6 shows the state of the land during the period of speculation. Approximately 27 percent of the respondents said they would allow the land to remain idle in the process waiting for the right time for sale. Approximately 68 percent claimed that they had fenced and built a hut (small house) waiting for price increases. In addition, 5 percent said they were informally selling the land to land speculators. Holding land idle without development has been a serious problem for towns and cities in Ethiopia's sustainable growth. For instance, during the implementation of the First structural Plan $1975 / 2005$, it was realized that individual ownership of land and speculation in urban land had led to the substantial and continuing increase in the cost of land acquisition. 


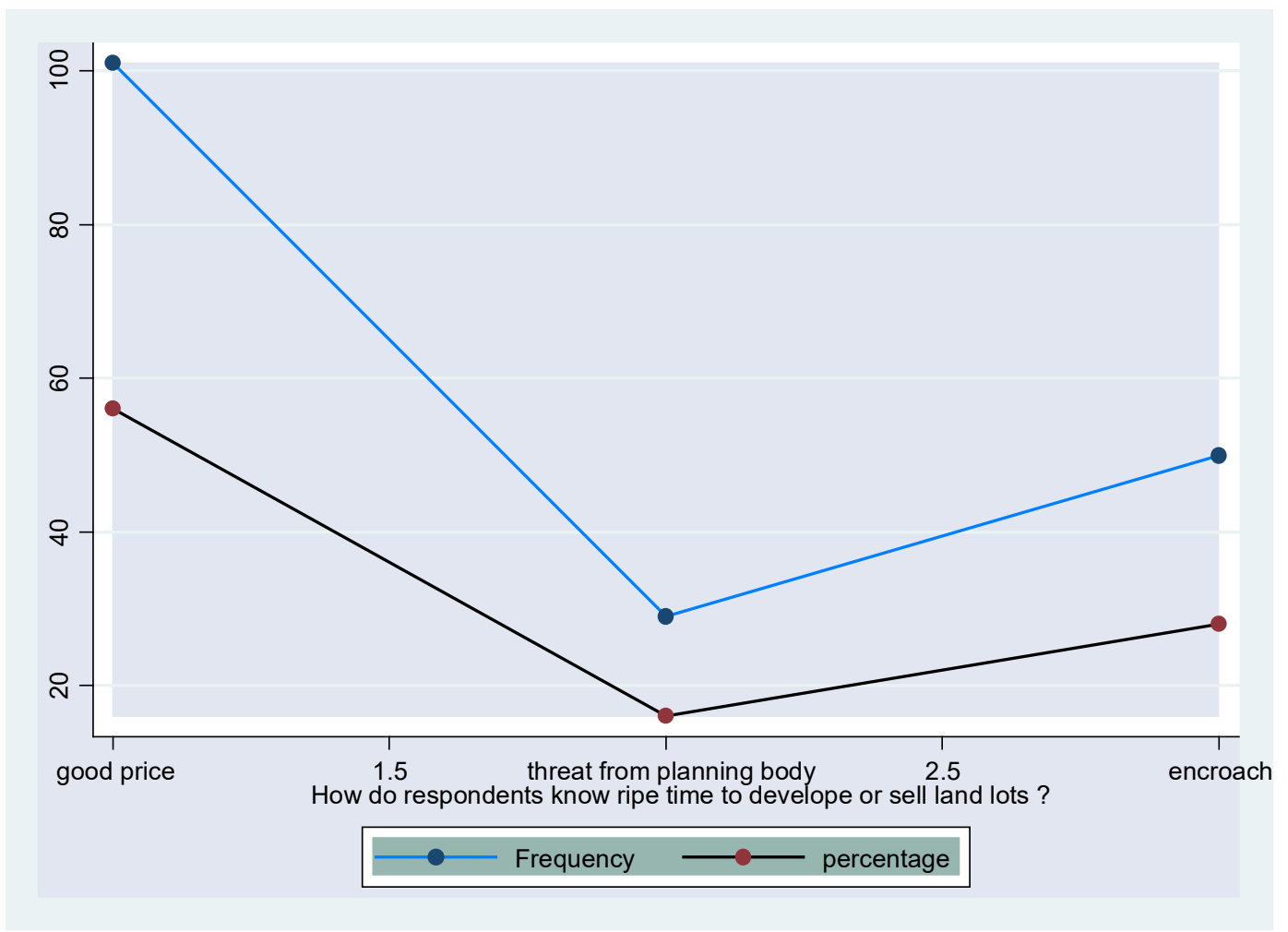

Figure 7. How do respondents know the ripe time to develop or sell land lots? Source: Researcher fieldwork 2017

Many community agencies and private organizations lamented land acquisition as one of the most challenging factors that delayed the completion of their development projects. Despite the continuation of the above legislation empowering the government to compulsorily acquire land for public purposes, it had become difficult to do so at reasonable cost and in a reasonable time, especially in some of the city's densely populated urban centers. One of the declaration's main goals is to check land speculators ' excesses, but different land allocation policies, especially during the civilian era, were very scandalous as only friends, party stalwarts and relatives gained access to land. As one government succeeds the other, these allocations are often withdrawn. In essence, the Land Use Decree of 1991 did not eliminate land speculation, but either drove it underground or fuelled it.

Figure 7 shows that how respondents know when they are ready to sell their land. About 56 percent of the respondents said it was high time the land was disposed of when a good price was offered or when the land prices in the area started to rise. Similarly, 16 and 28 percent of respondents said they knew the mature time the very moment they were starting to practice threats from planners or when building activity was invading their land. It is a fact that the whole idea of speculation is to store up huge track of land that is kept undeveloped in expectation of an increase in the value of its site. Most speculators release their land the moment they are paid a fair price for the land.

Examining whether speculators were ever challenged by planning bodies reveals that $72.6 \%$ of respondents said no; while $27.4 \%$ said yes (see Figure 8 ). Those who responded yes stated that they were confronted by planning bodies over the nondevelopment of the allocated land. At this point, it is relevant to stress that, despite the fact that the announcement of land use in 1991 facilitated access to land for public use, it did not achieve the same goals as regards land for private use (Udo, 1990).The announcement according to Onokerhoraye (2010) has deficiencies and these are evident in its implementation rather than its structure or intendment. The objectives for which the verdict was promulgated have largely remained unfulfilled. Those in charge of ensuring compliance to the provisions of the decree have distorted, battered and gravely demoralize the verdict and these led to boost in land speculation in metropolitan Shashemene. The response in Figure 8 which articulates that $83 \%$ of the speculators was never challenged by planning bodies attest to the inefficiency of the planning agencies in ensuring compliance with the provision of the 1991 Land Use Declaration. 


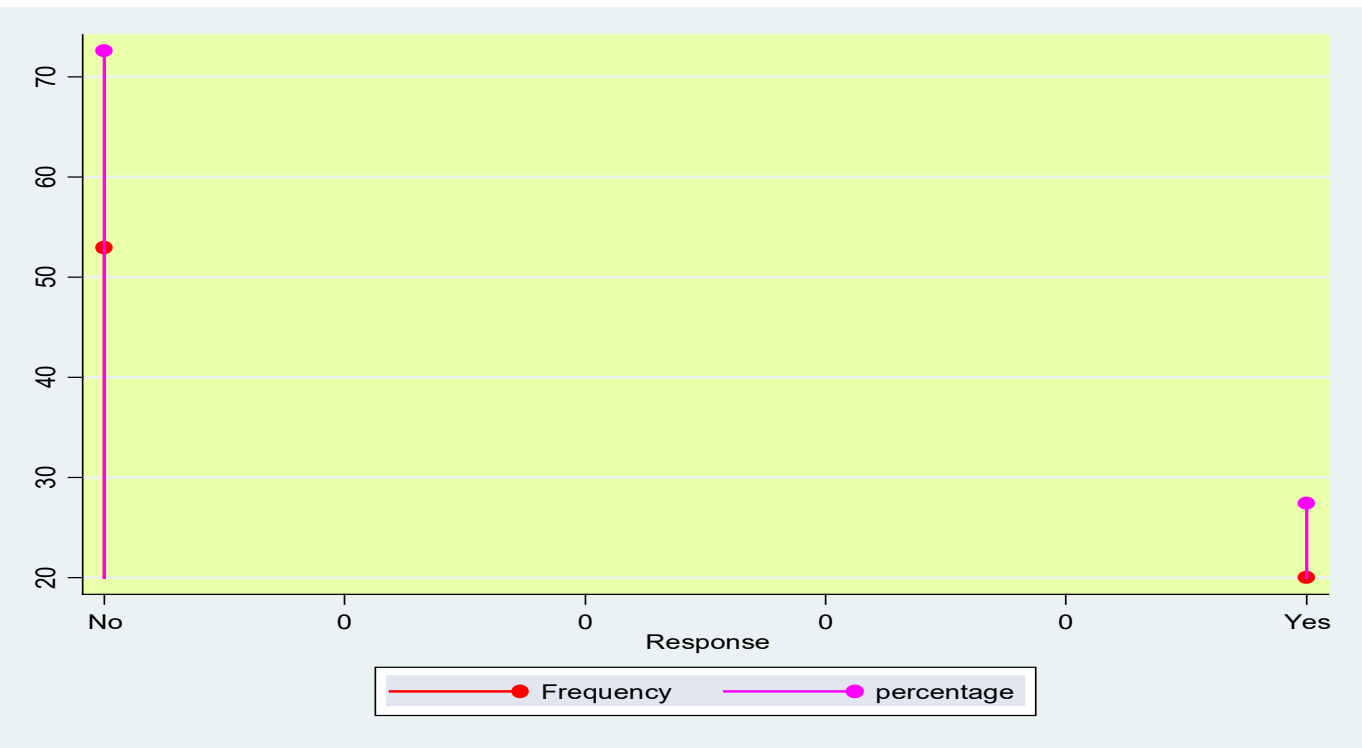

Figure 8. Whether respondents were ever challenged by planning body? Source: Researcher fieldwork 2017

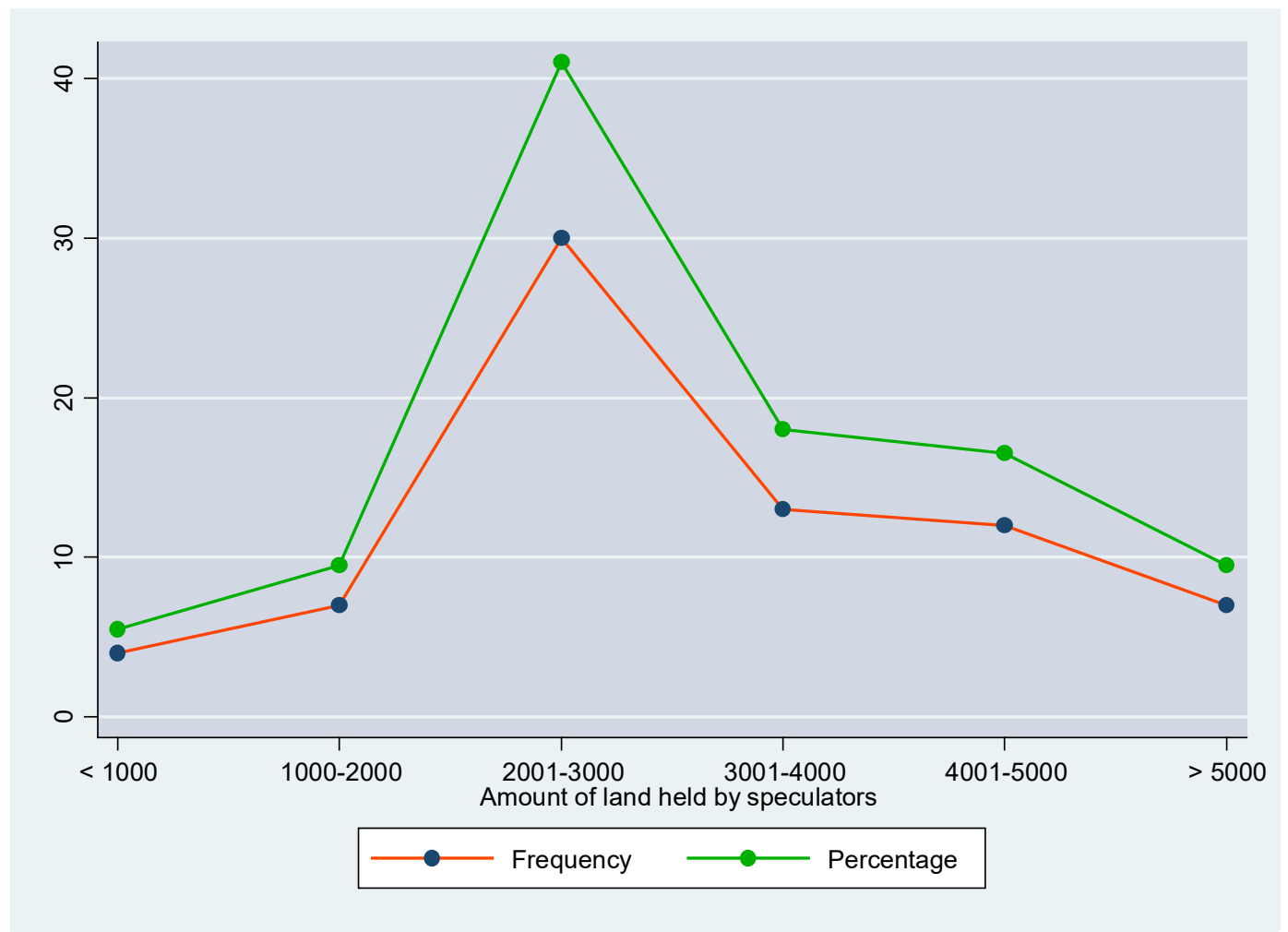

Figure 9. Quantity of landholding currently held by the land speculators Source: Researcher fieldwork 2017

With respect to the number of land lots held by respondents, $5.5 \%$ of the respondents hold $<1000 \mathrm{~m}^{2}$ of land, $9.5 \%$ hold between $1000-2000 \mathrm{~m}^{2}, 41 \%$ holds between $2001-3000 \mathrm{~m}^{2}$ and 9.5 hold over $5000 \mathrm{~m}^{2}$ of land (see Figure 9). Some respondents particularly those engaged in property development stated that they hold such land as land banks. Land banks are held by developers to ensure constant flow or supply of building land and to ensure the production flow of dwellings. The advantages of maintaining a land bank to a developer is to plan continuity of his operation and in the same vein where they have a monopoly over the supply of development land it may enable them to influence zoning as well as prices of land. Similar findings were noted by Rydin (1983) and Markusen and Scheffman (1977).

It is important to stress here that a land bank may comprise of the multiple number of plots in one location. Despite the fact that this study did not inquire into the size and extent of the land banks, data analysis revealed a significant insight into how respondents plan continuity of their activity (Figure 9). 


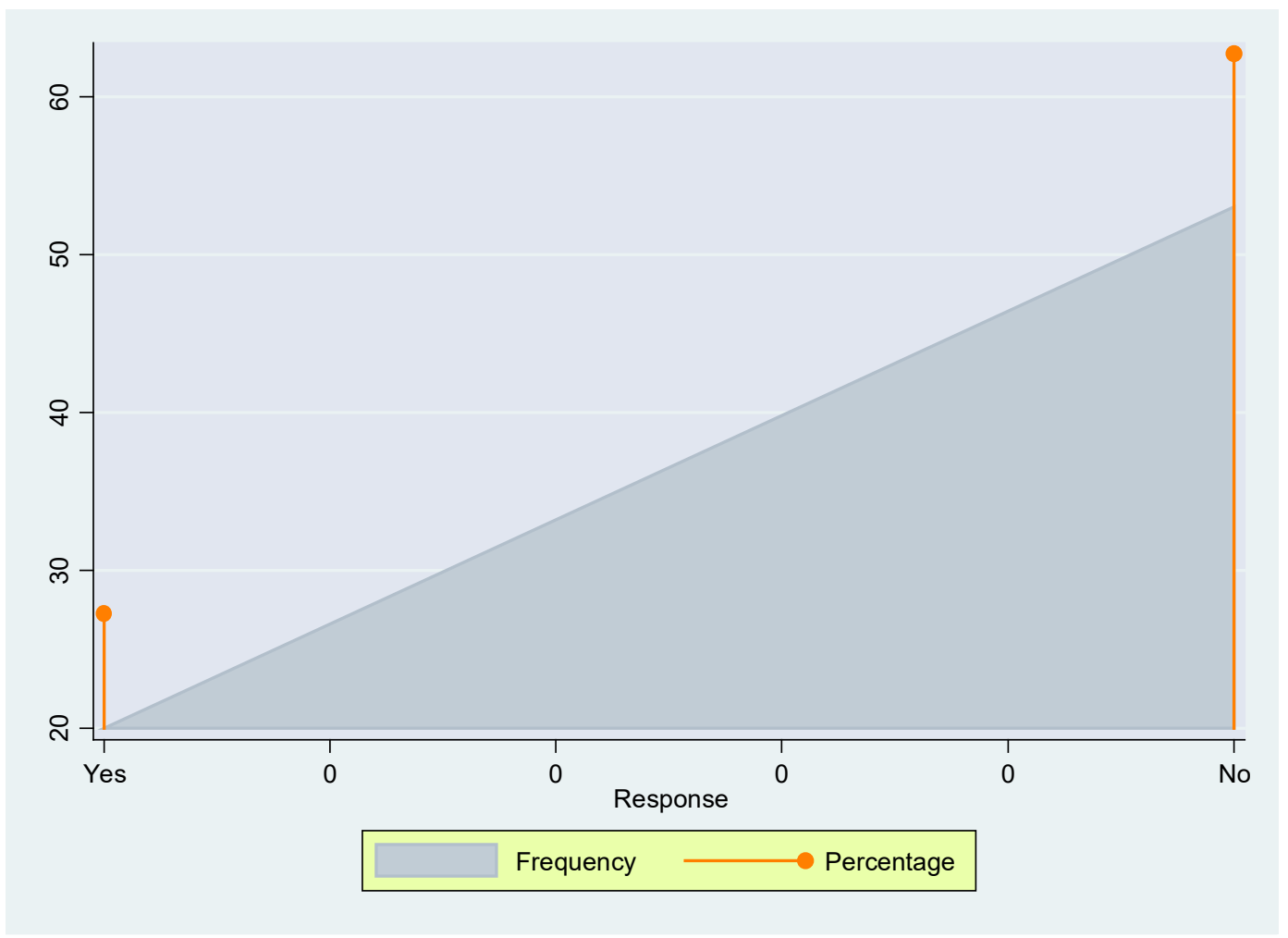

Figure 10. Whether the speculators experience risk in speculation

It is marked by the character of the land speculation that it may be liable to menace; principally that the 1991 Land Use announcement prohibits speculation of any sort. Data in Figure 10 shows that $27.3 \%$ of the respondents argued that they have practice on the form of menace or the other while the mass (62.7\%) argued they do not practice any risks in land speculation. Additional analysis of the character of risks sampled respondents practices demonstrate that the respondents practice loss of first investment, revocation of land by the government as well as disputes and numerous sales of the plot of land.

\section{CONCLUSION}

This study looks at the role of land speculators around Shashemene Metropolis' urban edge. The study acknowledges that, despite the fact that the 1991 Land Use Declaration's provision has as one of its main goals the control of land speculators' excesses, the act of speculation is still common in. the societies. Similarly, in its provisions, for example in the areas of tenure security and its definition of land improvement, the declaration was also found wanting. Many people still have to fully register their land and obtain an occupancy certificate and land is still widely acquired through the in. Official market. Similarly, there is uncertainty about the definition of land development or improvement, which allows speculators to abuse or disfigure the declaration's provisions. Land speculation has caused severe distortion of towns and cities' orderly development and facilitated urban sprawl. It is, therefore, the rivalry of this study that land speculation might live on until the ambiguities in the 1991 land use announcement and its implementation are significantly.

\section{RECOMMENDATIONS}

The following suggestions are hereby put forward: i) the government should strive to bring the provisions of the 1991 land use decree into conformity with its present commitment to democratic principles and the operations of the free market economy ii) the enforcement capacity of Local Planning Boards to implement the provisions of planning laws and regulations for the orderly development of the city should be considerably strengthened iii) introduction of property taxation; several people have been buying up tracts of rural land for speculative purposes in the absence of property rating in the form of land taxes. Tenement ratings should be intensified in the urban centers where it already exists and introduced all over the country as a means of generating revenue for the government. The foreword of land taxation is probable to vigor the people to use their land more intensively to pay taxes, lessen the price of land due to capitalization cause or vigor people to organize off their land as a consequence of holding price effect of tax on the landowners, depending on the site of the land and their anticipation of future prices. 


\section{REFERENCES}

Abrahamson, M. (1983). Social Research Methods. London, UK: Prentice-Hall.

Adam, A. G. (2014c). Peri-urban land rights in the era of urbanisation in Ethiopia: A property rights approach. African Review of Economics and Finance, 6(1), 120-138.

Andreasson, P., Bekiros, S., Nguyen, D. K., \& Uddin, G. S. (2015). Impact of Speculation and Economic Uncertainty on Commodity Markets. International Review of Financial Analysis, 100(7), 1-17.

Bentick, B. L. (1972). Improving the Allocation of Land between Speculators and Users: Taxation and paper land. Econ. Rec., 48, 18. https://doi.org/10.1111/j.1475-4932.1972.tb01534.x

Capozza, D. R. (1976). The efficiency of speculation in urban land. Environ. Plann. A, 8, 411-412. https://doi.org/10.1068/a080411

Colin, J. (2013). Securing Rural Land Transactions in Africa. An Ivorian Perspective. Land Use Policy, 31, 430-440. https://doi.org/10.1016/j.landusepol.2012.08.006

CSA-Central Statistical Agency. (2007). National Housing and Population Census, Addis Ababa Central Statistical Agency 2013, National population projection for 2013. Available at: http://www.citypopulation.de/Ethiopia.html

Fabiyi, Y. L. (1984). Land administration in Nigeria: Case studies of the implementation of the land use decree (Act) in Ogun, Ondo and Oyo States of Nigeria. Agric. Admin., 17, 21-31. https://doi.org/10.1016/0309-586X(84)90060-8

FDRE (2005a). Expropriation of Land Holdings for Public Purpose and Payment of Compensation Proclamation. Federal Democratic Republic of Ethiopia Proclamation No.455/2005. Addis Ababa, Ethiopia.

Federal Government of Nigeria. (2006). National urban policy. Federal Ministry of Urban Development and Housing, Abuja, Nigeria.

Mamman, A. B. (1996). The nature and effect of the activities of private residential developers in Sokoto.Proceedings of the 3rd National Workshop on Land Administration and Development in Northern Nigeria, March 12-16, 1995, Bayero University Kano, Nigeria.

Markusen, J. R., \& Scheffman, D. T. (1977). Ownership Concentration in the Urban Land Market: Analytic Foundations and Empirical Evidence in Public Property. In L. M. Smith and M. Walker (Eds.) The Habitat Debate Continues. Prentice-Hall, Vancouver, Canada, pp. 147-176.

Mayo, S. R., \& Sheppard, S. (2001). Housing supply and the effects of stochastic development control. J. Housing Econ., 3, 109-128. https://doi.org/10.1006/jhec.2001.0283

NPC. (1991). Population census report. National Population Commission (NPC), Lagos, Nigeria. NPC, 2007. Population census preliminary report. National Population Commission (NPC), Lagos, Nigeria.

Obikeze, D. S. (1986). Introductory Statistics for Social Science. Enugu, Nigeria: Fourth Dimension Ltd.

Onokerhoraye, A. G. (2010). Land reform and challenges for vision 20:2020. 4th Annual Lecture Faculty of Environmental Sciences. Awka, Nigeria: Nnamdi Azikiwe University.

Rydin, Y. (1983). State involvement in the residential development process through the operation of development control; The local impact of circulars 9/80 and 22/80. Paper Presented at Conference on Land Policy: Problems and Alternatives, Polytechnic, Oxford.

Shashemene Woreda Finance and Economic Development (SWFED) (2018). Secondary data collected from Shashemene Woreda Finance and Economic Development Office.

Titman, S. (1985). Urban land prices under uncertainty. Am. Econ. Rev., 75, 505-514.

Udo, R. (1990). Land Use Policy and Land Ownership in Nigeria. Lagos, Nigeria: Ebieakwa Ventures.

Urquhart, A. W. (1977). Planned Urban Landscapes of Northern Nigeria. Zaria, Nigeria: Ahmadu Bello University Press.

World Bank. (1996). Astrategy for restoring urban infrastructure and services in Nigeria. World Bank Findings (Africa Region, Number 62), Washington, DC., USA., pp. 1-5.

Yirsaw, B. (2010). Urban Land Lease Policy of Ethiopie: Case Study on Addis Ababa and Lease Towns of Amhara National Regional State Sydney, Australia, 11-16 April 2010. 